\title{
Bioaccumulation of Some Potentially Toxic Heavy Metals in Freshwater Fish of River Shah Alam, Khyber Pakhtunkhwa, Pakistan
}

\author{
Hazrat Ali ${ }^{1,2, *}$, Ezzat Khan ${ }^{1, *}$ and Muhammad Jamal Nasir ${ }^{3}$ \\ ${ }^{1}$ Department of Chemistry, University of Malakand, Chakdara 18800, Dir Lower, \\ Khyber Pakhtunkhwa \\ ${ }^{2}$ Green \& Environmental Chemistry, Ecotoxicology and Ecology Laboratory, \\ Department of Zoology, University of Malakand, Chakdara 18800, Dir Lower, Khyber \\ Pakhtunkhwa \\ ${ }^{3}$ Department of Geography, University of Peshawar, Peshawar, Khyber Pakhtunkhwa
}

\begin{abstract}
A B S T R A C T
The present study was designed to assess the concentrations of $\mathrm{Cr}, \mathrm{Ni}, \mathrm{Cd}$ and $\mathrm{Pb}$ in water, sediments and different fish species of River Shah Alam, a tributary of River Kabul in Khyber Pakhtunkhwa, Pakistan. The different environmental samples were collected from the river, downstream the city of Peshawar, and analyzed for the selected heavy metals by atomic absorption spectrophotometry. Heavy metal accumulation was studied in muscles of six fish species collected from the river. Heavy metal accumulation was also studied in other tissues such as skin, gills, liver and kidneys of two fish species i.e., Clupisoma naziri and Mastacembelus armatus. Cr concentrations in fish muscles ranged from $30.5 \pm 41.9$ to $70.8 \pm 12.1 \mathrm{mg} \mathrm{kg}^{-1}$ wet weight, $\mathrm{Ni}$ from $16.7 \pm 10.2$ to $103.5 \pm 114.1 \mathrm{mg} \mathrm{kg}^{-1}$ wet weight, $\mathrm{Cd}$ from $1.1 \pm 0.18$ to $2.5 \pm 0.21 \mathrm{mg} \mathrm{kg}^{-1}$ wet weight and $\mathrm{Pb}$ from $29.7 \pm 18.3$ to $97.7 \pm 95.4 \mathrm{mg} \mathrm{kg}^{-1} \mathrm{wet}_{\text {weight. }}$ Metal concentrations in muscle samples of the different six fish species showed random variations. Interspecies differences were statistically not significant, most probably due to more variance within samples. Comparative metal accumulation in the five different tissues of C. naziri and M. armatus did not show a consistent trend across the studied tissues.
\end{abstract}

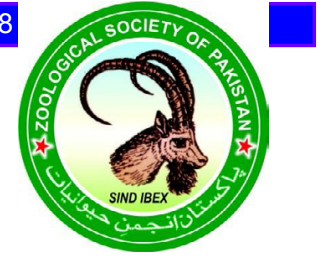

CrossMark

Article Information

Received 17 November 2017

Revised 22 June 2018

Accepted 30 January 2019

Available online 20 January 2020

Authors' Contributions

HA and EK conceived and designed

the study. HA collected, prepared and

analyzed the samples. HA analyzed

the data and wrote the manuscript.

MJN contributed to data analysis. EK

supervised the research work.

Key words

Bioaccumulation, Fish, Heavy metals,

River Shah Alam, Sediments, Water.

\section{INTRODUCTION}

$\mathrm{H}$ eavy metals released into the environment from variety of natural and anthropogenic sources. Vehicle traffic is among the major anthropogenic sources of heavy metals such as $\mathrm{Cr}, \mathrm{Zn}, \mathrm{Cd}$ and $\mathrm{Pb}$ (Ferretti et al., 1995). Environmental monitoring of river water is important for protecting aquatic life (Ebadi and Hisoriev, 2017). Assessment of heavy metal accumulation in fish is important from public health point of view because of their consumption by humans (Ali et al., 2017).

$\mathrm{Cd}$ and $\mathrm{Pb}$ are biologically non-essential heavy metals. Cd is among the most toxic heavy metals (Bernard, 2008). A recent study conducted in China on a large adult population has found an association between blood $\mathrm{Pb}$ levels and an increased prevalence of cardiovascular diseases (CVD) (Chen et al., 2017). Apart from affecting the fish consumers, heavy metals also affect the exposed fish. Exposure of fish to heavy metals disrupts secretion

\footnotetext{
Corresponding authors: hazrataliuom@gmail.com; hazratali@uom.edu.pk; ekhan@uom.edu.pk 0030-9923/2020/0002-0603 \$ 9.00/0 Copyright 2020 Zoological Society of Pakistan
}

of reproductive hormones and causes pathological changes (Ebrahimi and Taherianfard, 2011). Cr causes biochemical, hematological and behavioral changes in fish (Aslam and Yousafzai, 2017). It has been found that exposure to $\mathrm{Cr}$ changed locomotor behavior in the fish Gambusia affinis. It also caused adverse effects such as morphological changes, necrosis and periodic hemorrhages in the gills of the exposed fish (Begum et al., 2006). It has been reported that exposure to $\mathrm{Pb}$ at sublethal concentrations has a potential immuno-suppressor effect on tilapia fish (Oreochromis mossambicus) (Kaya et al., 2013).

Industrialization and urbanization as well as rapid population growth and economic development have caused deterioration of environmental quality and contamination of freshwater ecosystems with various toxic chemicals including heavy metals. Rivers are freshwater ecosystems, which are much vulnerable to environmental changes and pollution. River Shah Alam is a severely polluted tributary of River Kabul (Khan et al., 1999), which receives wastewaters from different industries including distilleries, ghee mills, paper mills, sugar mills, tanneries, and textile mills (Khan et al., 2011). The present study was designed to assess the concentrations of four heavy metals i.e., $\mathrm{Cr}, \mathrm{Ni}, \mathrm{Cd}$ and $\mathrm{Pb}$ in the water, sediments and different 
freshwater fish of River Shah Alam, Khyber Pakhtunkhwa, Pakistan. Accumulation of the selected heavy metals was studied in muscles because this tissue is the edible part of the fish and is the most important from human health point of view. However, comparative metal accumulation was also studied in different tissues of two fish species i.e., Clupisoma naziri and Mastacembelus armatus.

\section{MATERIALS AND METHODS}

River Shah Alam is a tributary of River Kabul, and receives sewage from Peshawar city through Ganda Erab and Budni Nalla and from 30 villages in the surroundings. Therefore, River Shah Alam is considered as a more polluted river (Khan et al., 2012). A map of the study area showing the sampling site is given in Supplementary Figure S1.

Water, sediment and fish samples were collected at the sampling site $\left(34^{\circ} 04^{\prime} 04^{\prime \prime} \mathrm{N}\right.$ and $\left.71^{\circ} 38^{\prime} 54^{\prime \prime} \mathrm{E}\right)$ on River Shah Alam. This sampling site was selected because it is downstream to the point where Budni Nalla, carrying polluted water from Peshawar, joins River Shah Alam. The environmental samples were collected according to Csuros and Csuros (2002) and transported to the laboratory with proper care and arrangements. Water samples were prepared according to Malik and Maurya (2014), sediment samples were digested according to Jan et al. (2010) while the fish samples were digested according to Javed and Usmani (2016) with modifications. A $50 \mathrm{~mL}$ water sample was acidified with $5 \mathrm{~mL}$ concentrated $\mathrm{HNO}_{3}$ and evaporated at $80^{\circ} \mathrm{C}$ on a hot plate until its volume was reduced to $50 \mathrm{~mL}$. After filtration, the water sample was taken in a $50 \mathrm{~mL}$ volumetric flask. Sediment samples were air dried and passed through a less than $2 \mathrm{~mm}$ sieve. A 0.5 $\mathrm{g}$ dried and finely powdered sediment sample was digested with $10 \mathrm{~mL}$ aqua regia $\left(\mathrm{HCl}: \mathrm{HNO}_{3}, 3: 1\right.$ ratio). Fish muscle samples were taken from the dorsal side, behind the dorsal fin. A $1.0 \mathrm{~g}$ muscle sample (wet weight basis) was digested with a $10 \mathrm{~mL}$ mixture of $\mathrm{HNO}_{3}$ and $\mathrm{HClO}_{4}, 3: 1$ ratio. Digestion was carried out at $80^{\circ} \mathrm{C}$ on a hot plate. The four selected heavy metals i.e., $\mathrm{Cr}, \mathrm{Ni}, \mathrm{Cd}$ and $\mathrm{Pb}$ were quantified in the prepared samples with Flame Atomic Absorption Spectrophotometer (Perkin-Elmer Model No. 2380). Quality assurance tests were done to establish the reliability of metal analysis (Supplementary Table I).

Results are shown as mean \pm standard deviation, from three independent experiments. Data were analyzed with SPSS version 16. Mean metal concentrations at different study sites were compared using One-Way ANOVA (Tukey Test). A $p$-value of 0.05 was considered for statistical significance.

\section{RESULTS AND DISCUSSION}

Table I shows the concentrations of the four heavy metals in the water and sediments of River Shah Alam. The concentrations of these metals in both water and sediments followed the order: $\mathrm{Ni}>\mathrm{Cr}>\mathrm{Pb}>\mathrm{Cd}$. Previously, Khan et al. (2011) have reported the concentrations $\left(\mathrm{mg} \mathrm{L}^{-1}\right)$ of heavy metals in water of River Shah Alam as: $\mathrm{Cr}(0.02)$, $\mathrm{Ni}$ (0.65), $\mathrm{Cd}$ (0.03), and $\mathrm{Pb}$ (0.09), which are lower than the current levels. Usman et al. (2017) have reported $\mathrm{Cr}$, $\mathrm{Cd}$ and $\mathrm{Pb}$ concentrations of 0.04-2.0, 0.2-0.69 and 1.0-1.2 $\mathrm{mg} \mathrm{L}^{-1}$, respectively in water of River Shah Alam, which are higher than our reported concentrations. Tabinda et al. (2013) have reported $\mathrm{Cr}$ and $\mathrm{Ni}$ concentrations of $0.16 \pm$ 0.89 and $0.04 \pm 0.03 \mathrm{mg} \mathrm{L}^{-1}$, respectively in water from River Sutlej, Pakistan, which are lower than our reported concentrations. Ebadi and Hisoriev (2017) have reported $\mathrm{Cr}, \mathrm{Cd}$ and $\mathrm{Pb}$ concentrations of 2.1-4.6, 0.01-0.59 and $1.9-4.2 \mathrm{mg} \mathrm{L}^{-1}$, respectively in water from different sites of Tajan River, Iran; these values are also higher than our reported concentrations.

Table I.- Concentrations (mean $\pm \mathrm{SD}, \mathbf{n}=3$ ) of four potentially toxic heavy metals in water and sediments of River Shah Alam, Khyber Pakhtunkhwa, Pakistan.

\begin{tabular}{lcc}
\hline Metal & $\begin{array}{c}\text { Concentration in } \\
\text { water }\left(\mathbf{m g ~ L}^{-\mathbf{1}}\right)\end{array}$ & $\begin{array}{c}\text { Concentration in sediments } \\
\mathbf{( m g ~ k g}^{-\mathbf{1}} \mathbf{~ d r y ~ w e i g h t ) ~}\end{array}$ \\
\hline $\mathrm{Cr}$ & $0.80 \pm 0.32$ & $47.0 \pm 20.9$ \\
$\mathrm{Ni}$ & $2.4 \pm 1.0$ & $159.3 \pm 150.8$ \\
$\mathrm{Cd}$ & $0.05 \pm 0.02$ & $4.4 \pm 0.42$ \\
$\mathrm{~Pb}$ & $0.44 \pm 0.15$ & $36.3 \pm 19.1$ \\
\hline
\end{tabular}

Tabinda et al. (2013) have reported $\mathrm{Cr}$ and $\mathrm{Ni}$ concentrations of $35.0 \pm 7.3$ and $21.8 \pm 5.2 \mathrm{ppm}$ respectively in sediments from River Sutlej, Pakistan, which are lower than our reported concentrations. Miri et al. (2015) have reported $\mathrm{Cd}, \mathrm{Ni}$ and $\mathrm{Pb}$ concentrations of 0.22-5.8, 10.0-17.6 and 5.6-14.9 ppm, respectively in sediments of Chabahar Bay, Iran, which are also lower than our reported concentrations. Metal concentrations in both water and sediments depend on several factors and fluctuate from site to site due to their variable natural and anthropogenic sources. The anthropogenic sources of the selected heavy metals in the study area are agricultural run-off, domestic sewage and industrial effluents.

Table II shows metal concentrations in muscles of the different fish species. Metal concentrations in muscle samples of the different six fish species showed random variations. A high degree of randomness in heavy metal distribution has also been reported in the muscles of 
different six fish species from five freshwater lakes of Pakistan (Tariq et al., 1991). Inter-species differences were statistically not significant, most probably due to more variance within samples. Table III shows a comparison of concentrations of the four potentially toxic heavy metals in muscles of fish reported by the present study with those reported in fish from some other freshwater bodies.

Our reported heavy metal concentrations in fish muscles are generally higher than or comparable to those reported by the above-mentioned studies. However, our reported heavy metal concentrations are lower than those reported by Siraj et al. (2014) in muscles of fish collected from River Kabul near Nowshera. Similarly, Ahmad et al. (2015) have reported heavy metal concentrations, much higher than our reported values, in muscles of different edible fish species from River Kabul. Thus, our reported concentrations are lower than those reported by these two studies from River Kabul, Pakistan, the most relevant river for River Shah Alam. As mentioned in the introduction, River Shah Alam is a tributary of River Kabul; both are relatively polluted water bodies in the province because they receive industrial effluents, domestic sewage and agricultural run-off from Peshawar and adjacent areas.

Table II.- Metal concentrations (mean $\pm \mathrm{SD}, \mathbf{n}=3$ ) in muscles of different fish species from River Shah Alam, Khyber Pakhtunkhwa, Pakistan.

\begin{tabular}{lcccc}
\hline Fish species & \multicolumn{4}{c}{ Metal concentration $\mathbf{~} \mathbf{m g ~ k g}^{-\mathbf{1}}$ wet weight) in muscles } \\
\cline { 2 - 5 } & $\mathbf{C r}$ & $\mathbf{N i}$ & $\mathbf{C d}$ & $\mathbf{P b}$ \\
\hline Barilius vagra & $40.2 \pm 39.4$ & $58.3 \pm 39.9$ & $1.9 \pm 0.94$ & $29.7 \pm 18.3$ \\
Clupisoma naziri & $31.0 \pm 28.5$ & $103.5 \pm 114.1$ & $2.5 \pm 0.21$ & $62.7 \pm 51.9$ \\
Glyptothorax cavia & $30.5 \pm 41.9$ & $78.0 \pm 53.2$ & $1.5 \pm 0.52$ & $57.2 \pm 49.5$ \\
Glyptothorax punjabensis & $32.2 \pm 21.0$ & $99.7 \pm 44.3$ & $2.0 \pm 0.76$ & $40.5 \pm 30.1$ \\
Mastacembelus armatus & $57.5 \pm 12.5$ & $72.7 \pm 93.0$ & $1.4 \pm 0.28$ & $97.7 \pm 95.4$ \\
Notopterus chitala & $70.8 \pm 12.1$ & $16.7 \pm 10.2$ & $1.1 \pm 0.18$ & $51.0 \pm 46.5$ \\
\hline
\end{tabular}

Table III.- Comparison of concentrations of the four potentially toxic heavy metals in muscles of fish reported by the present study with those reported in fish from some other freshwater bodies.

\begin{tabular}{|c|c|c|c|c|c|c|c|}
\hline \multirow[t]{2}{*}{ Country } & \multirow{2}{*}{$\begin{array}{l}\text { Freshwater } \\
\text { body }\end{array}$} & \multirow[t]{2}{*}{ Fish species } & \multicolumn{4}{|c|}{ Concentration $\left(\mu \mathrm{g} \mathrm{g}^{-1}\right)$} & \multirow[t]{2}{*}{ Reference } \\
\hline & & & $\mathrm{Cr}$ & $\mathrm{Ni}$ & Cd & $\mathbf{P b}$ & \\
\hline \multirow[t]{5}{*}{ Bangladesh } & Buriganga river & Puntius ticto $\mathrm{ww}$ & $5.5 \pm 1.5$ & $1.6 \pm 0.27$ & - & - & Ahmed et al. (2016b) \\
\hline & & Puntius sophore ww & $4.3 \pm 1.4$ & $1.2 \pm 0.30$ & - & - & \\
\hline & & Puntius chola ww & $3.6 \pm 1.6$ & $1.0 \pm 0.52$ & - & - & \\
\hline & & Labeo rohita ww & $18.8 \pm 1.7$ & $6.6 \pm 0.24$ & - & - & \\
\hline & & Glossogobius giuris ww & $5.1 \pm 1.0$ & $0.73 \pm 0.19$ & - & - & \\
\hline India & River Ganga & $\begin{array}{l}\text { Mastacembelus armatus } \\
\text { ww }\end{array}$ & $19.7 \pm 1.1$ & $4.6 \pm 0.9$ & $4.4 \pm 0.9$ & $30.3 \pm 6.4$ & Pandey et al. (2017) \\
\hline \multirow[t]{3}{*}{ Pakistan } & Tarbela Lake & Catla catla & $0.17 \pm 0.03$ & $0.26 \pm 0.06$ & - & $0.16 \pm 0.04$ & Ahmed et al. (2016a) \\
\hline & & Cyprinus carpio & $0.23 \pm 0.07$ & $0.22 \pm 0.05$ & - & $0.23 \pm 0.03$ & \\
\hline & & Tor putitora & $0.18 \pm 0.02$ & $0.18 \pm 0.02$ & - & $0.18 \pm 0.02$ & \\
\hline Pakistan & River Swat & Oncorhynchus mykiss & $0.23 \pm 0.06$ & $0.19 \pm 0.02$ & - & $0.16 \pm 0.04$ & Ahmed et al. (2016a) \\
\hline \multirow[t]{3}{*}{ Pakistan } & River Kabul & Wallago attu & $533.3 \pm 206.1$ & $106.7 \pm 6.8$ & $68.0 \pm 15.0$ & $599.3 \pm 188.3$ & Ahmad et al. (2015) \\
\hline & & Cyprinus carpio & $489.0 \pm 49.7$ & $74.7 \pm 17.3$ & $53.3 \pm 2.9$ & $226.3 \pm 222.2$ & \\
\hline & & Labeo dyocheilus & $647.3 \pm 105.1$ & $117.7 \pm 33.5$ & $66.7 \pm 8.5$ & $528.7 \pm 236.4$ & \\
\hline \multirow[t]{2}{*}{ Pakistan } & River Kabul & Aorichthys seenghala ww & $565.3 \pm 148.7$ & $94.7 \pm 33.3$ & $60.7 \pm 17.2$ & $350.7 \pm 37.2$ & Siraj et al. (2014) \\
\hline & & Ompok bimaculatous ww & $703.0 \pm 125.3$ & $135.0 \pm 52.6$ & $71.7 \pm 12.1$ & $407.0 \pm 126.6$ & \\
\hline \multirow[t]{3}{*}{ Pakistan } & River Sutlej & Cirrhina mrigala & $2.0 \pm 0.74$ & $1.3 \pm 0.67$ & - & - & Tabinda et al. (2013) \\
\hline & & Labeo rohita & $1.8 \pm 0.84$ & $1.2 \pm 0.50$ & - & - & \\
\hline & & Catla catla & $1.5 \pm 0.49$ & $1.1 \pm 0.72$ & - & - & \\
\hline Pakistan & Freshwater lakes & Six fish species ww & $0.12-2.3$ & $0.14-2.7$ & $0.02-1.2$ & $0.06-4.1$ & Tariq et al. (1991) \\
\hline Pakistan & River Shah Alam & Six fish species ww & $30.5-70.8$ & $16.7-103.5$ & $1.1-2.5$ & $29.7-97.7$ & Present study \\
\hline
\end{tabular}

ww, wet weight. 

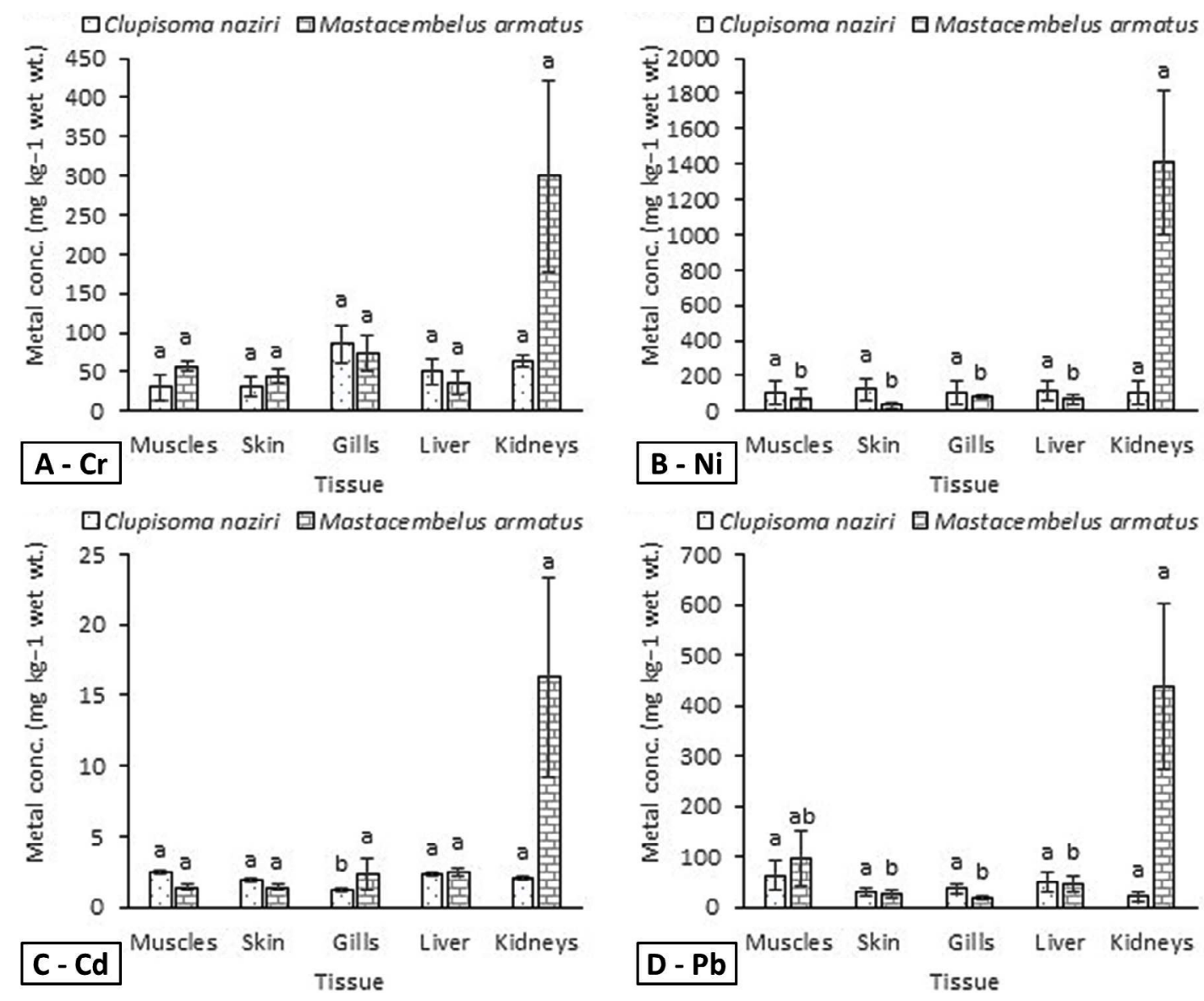

Fig. 1. Comparative accumulation of heavy metals in different tissues of Clupisoma naziri and Mastacembelus armatus.

Apart from assessment of heavy metal levels in fish muscles from natural water bodies such as rivers and lakes, some studies have investigated levels of heavy metals in fish from commercial fish farms. For example, Nawaz et al. (2010) have reported Cd concentrations in fish muscles as 0.40 and $0.35 \mu \mathrm{g} \mathrm{g}^{-1}$ in edible and non-edible fish respectively from River Ravi, Pakistan while $0.45 \mu \mathrm{g} \mathrm{g}^{-1}$ in edible farmed fish from fish farms at Manawan, Lahore. Their reported $\mathrm{Pb}$ concentrations in fish muscles were 2.7 and $2.1 \mu \mathrm{g} \mathrm{g}^{-1}$ in edible and non-edible fish, respectively from River Ravi, Pakistan while $3.0 \mu \mathrm{g} \mathrm{g}^{-1}$ in edible farmed fish from fish farms at Manawan, Lahore.

Figure 1 shows the comparative accumulation of the four heavy metals in different tissues of $C$. naziri and $M$. armatus. Among fish tissues, usually higher metal accumulation is observed in metabolically active tissues such as liver, kidneys and gills as compared to muscles. In this study, metal concentrations in different tissues of the two studied fish species followed the following order; for $C$. naziri: $\mathrm{Cr}$, gills $>$ kidneys $>$ liver $>$ skin $=$ muscles; $\mathrm{Ni}$, skin $>$ liver $>$ gills $>$ kidneys $>$ muscles; $\mathrm{Cd}$, muscles
$>$ liver $>$ kidneys $>$ skin $>$ gills; $\mathrm{Pb}$, muscles $>$ liver $>$ gills $>$ skin $>$ kidneys; for M. armatus: $\mathrm{Cr}$, kidneys $>$ gills $>$ muscles $>$ skin $>$ liver; Ni, kidneys $>$ gills $>$ muscles $>$ liver $>$ skin; Cd, kidneys $>$ liver $>$ gills $>$ muscles $\cong$ skin; $\mathrm{Pb}$, kidneys $>$ muscles $>$ liver $>$ skin $>$ gills.

Rauf et al. (2009) have reported highest $\mathrm{Cd}$ and $\mathrm{Cr}$ accumulation in liver among six fish tissues for three major carps from River Ravi, Pakistan. MohammadiRouzbahani (2017) has also reported gills and liver as the target tissues for accumulation of heavy metals in two fish species from the Persian Gulf, Iran. Khan et al. (2012) have reported heavy metal concentrations in different fish tissues as: liver $\geq$ gills $>$ muscles. Ahmed et al. (2016a) have found higher heavy metal accumulation in liver and skin than in gills and muscles.

Yousafzai and Shakoori (2008) have reported heavy metals concentrations ( $\mu \mathrm{g} \mathrm{g}^{-1}$ wet weight) in gills of the freshwater fish Tor putitora at control, polluted site 1 and polluted site 2 respectively of River Kabul, Pakistan as: $\mathrm{Cr}$ (5.3 $\pm 0.18,6.6 \pm 0.07$ and $6.0 \pm 0.38)$; $\mathrm{Ni}(53.3 \pm 8.4,128 \pm 8.8$ and $133 \pm 7.3) ; \mathrm{Pb}(219.3 \pm 31.4,313.7 \pm 29.9$ and $321 \pm 9.8)$. 
These values are lower $(\mathrm{Cr})$, comparable to $(\mathrm{Ni})$ and higher than $(\mathrm{Pb})$ our reported metal concentrations in gills of $C$. naziri and M. armatus.

\section{CONCLUSIONS}

Metal concentrations in muscle samples of the different six fish species showed random variations. A high degree of randomness in heavy metal distribution has also been reported in the muscles of different fish species from other freshwater bodies of Pakistan. Interspecies differences were statistically not significant, most probably due to more variance within samples.

Comparison with similar studies done in Pakistan shows that heavy metal levels reported in fish muscles by this study are generally higher than or comparable to those reported from other neighborhood rivers. However, our reported concentrations are lower than those reported by two studies from River Kabul, Pakistan, the most relevant river for River Shah Alam. As mentioned in the introduction, River Shah Alam is a tributary of River Kabul; both are relatively polluted water bodies in the province because they receive industrial effluents, domestic sewage and agricultural run-off from Peshawar and adjacent areas. Regarding tissue-specific metal accumulation, the five different tissues of $C$. naziri and $M$. armatus did not show a consistent trend across the studied tissues.

\section{ACKNOWLEDGEMENTS}

The authors are thankful to Prof. Dr. Rup Lal, Professor at Department of Zoology, University of Delhi, India, for gifting a copy of standard literature keys for fish identification and to Mr. Abdur Rahman, Lecturer in Zoology, and Fisheries Specialist at Department of Zoology, University of Malakand, for his help in fish identification. Dr. Muhammad Anwar Sajad, Department of Botany, Islamia College Peshawar, is also gratefully acknowledged for his cooperation in metal analysis. The authors are also thankful to the anonymous reviewer whose comments and suggestions greatly improved the quality of the manuscript.

\section{Supplementary material}

There is supplementary material associated with this article. Access the material online at: https://dx.doi. org/10.17582/journal.pjz/20171117161138

\section{Statement of conflict of interest}

The authors declare no conflict of interest.

\section{REFERENCES}

Ahmad, H., Yousafzai, A.M., Siraj, M., Ahmad, R.,
Ahmad, I., Nadeem, M.S., Ahmad, W., Akbar, N. and Muhammad, K., 2015. Pollution problem in River Kabul: Accumulation estimates of heavy metals in native fish species. BioMed Res. Int., 2015. Article ID 537368. https://doi.org/10.1155/2015/537368

Ahmed, M., Ahmad, T., Liaquat, M., Abbasi, K.S., Farid, I.B.A. and Jahangir, M., 2016a. Tissue specific metal characterization of selected fish species in Pakistan. Environ. Monitor. Assess., 188: 212. https://doi.org/10.1007/s10661-016-5214-6

Ahmed, M.K., Baki, M.A., Kundu, G.K., Islam, M.S., Islam, M.M. and Hossain, M.M., 2016b. . Human health risks from heavy metals in fish of Buriganga river, Bangladesh. SpringerPlus, 5: 1697. https:// doi.org/10.1186/s40064-016-3357-0

Ali, H., Ali, W., Ullah, K., Akbar, F., Ahrar, S., Ullah, I., Ahmad, I., Ahmad, A., Ilahi, I. and Sajad, M.A., 2017. Bioaccumulation of $\mathrm{Cu}$ and $\mathrm{Zn}$ in Schizothorax plagiostomus and Mastacembelus armatus from River Swat, River Panjkora and River Barandu in Malakand Division, Pakistan. Pakistan J. Zool., 49: 1555-1561. https://doi.org/10.17582/ journal.pjz/2017.49.5.1555.1561

Ali, H. and Khan, E., 2018. Environmental chemistry in the twenty-first century. Environ. Chem. Lett., 15: 329-346. https://doi.org/10.1007/s10311-0160601-3

Ali, H. and Khan, E., 2017b. What are heavy metals? long-standing controversy over the scientific use of the term 'heavy metals'-proposal of a comprehensive definition. Toxicol. environ. Chem., 100: 6-19. https://doi.org/10.1080/02772248.2017. 1413652

Aslam, S. and Yousafzai, A.M., 2017. Chromium toxicity in fish: A review article. J. Ent. Zool. Stud., 5: 1483-1488.

Begum, G., Rao, J.V. and Srikanth, K., 2006. Oxidative stress and changes in locomotor behavior and gill morphology of Gambusia affinis exposed to chromium. Toxicol. environ. Chem., 88: 355-365. https://doi.org/10.1080/02772240600635985

Bernard, A., 2008. Cadmium and its adverse effects on human health. Ind. J. med. Res., 128: 557-564.

Chen, C., Li, Q., Nie, X., Han, B., Chen, Y., Xia, F., Zhai, H., Wang, N. and Lu, Y., 2017. Association of lead exposure with cardiovascular risk factors and diseases in Chinese adults. Environ. Sci. Pollut. Res., 24: 22275-22283. https://doi.org/10.1007/ s11356-017-9200-5

Csuros, M. andCsuros,C.,2002.Environmental sampling and analysis for metals. Lewis Publishers, Boca Raton. https://doi.org/10.1201/9781420032345 
Ebadi, A.G. and Hisoriev, H., 2017. Metal pollution status of Tajan River - Northern Iran. Toxicol. environ. Chem., 99: 1358-1367. https://doi.org/10 $.1080 / 02772248.2017 .1345191$

Ebrahimi, M. and Taherianfard, M., 2011. The effects of heavy metals exposure on reproductive systems of cyprinid fish from Kor River. Iran. J. Fish. Sci., 10: $13-24$

Ferretti, M., Cenni, E., Bussotti, F. and Batistoni, P., 1995. Vehicle-induced lead and cadmium contamination of roadside soil and plants in Italy. Chem. Ecol., 11: 213-228. https://doi. org/10.1080/02757549508039072

Jan, F.A., Ishaq, M., Khan, S., Ihsanullah, I., Ahmad, I. and Shakirullah, M., 2010. A comparative study of human health risks via consumption of food crops grown on wastewater irrigated soil (Peshawar) and relatively clean water irrigated soil (lower Dir). $J$. Hazard. Mater., 179: 612-621.

Javed, M. and Usmani, N., 2016. Accumulation of heavy metals and human health risk assessment via the consumption of freshwater fish Mastacembelus armatus inhabiting, thermal power plant effluent loaded canal. SpringerPlus, 5: 776. https://doi. org/10.1186/s40064-016-2471-3

Kaya, H., Akbulut, M., Çelik, E.Ş. and Yılmaz, S., 2013. Impacts of sublethal lead exposure on the hematoimmunological parameters in tilapia (Oreochromis mossambicus). Toxicol. environ. Chem., 95: 15541564. https://doi.org/10.1080/02772248.2013.8693 32

Khan, A.R., Akif, M., Wadud, S. and Khan, K., 1999. Pollution studies of Kabul River and its tributes for the assessment of organic strength and fecal coliform. J. chem. Soc. Pak., 21: 41-47.

Khan, T., Muhammad, S., Khan, B. and Khan, H., 2011. Investigating the levels of selected heavy metals in surface water of Shah Alam River (A tributary of River Kabul, Khyber Pakhtunkhwa). J. Himalayan Earth Sci., 44: 71-79.

Khan, B., Khan, H., Muhammad, S. and Khan, T., 2012. Heavy metals concentration trends in three fish species from Shah Alam River (Khyber Pakhtunkhwa Province, Pakistan). J. Nat. environ. Sci., 3: 1-8.

Malik, D.S. and Maurya, P.K., 2014. Heavy metal concentration in water, sediment, and tissues of fish species (Heteropneustis fossilis and Puntius ticto) from Kali River, India. Toxicol. environ. Chem., 96: 1195-1206.

Miri, M., Nabavi, S.M.B., Doustshenas, B., Safahieh, A.R. and Loghmani, M., 2015. Levels of heavy metals in sediments in the vicinity of Chabahar Bay desalination plant. Iran. J. Fish. Sci., 14: 876-884.

Mohammadi-Rouzbahani, M., 2017. Heavy metal concentrations in different tissues of Euryglossa orientalis, Chirocentrus nudus and sediments in Bahrekan Bay (the northwest of Persian Gulf). Iran. J. Fish. Sci., 16: 945-958.

Morgan, A.J., 1986. Calcium-lead interactions involving earthworms: an hypothesis. Chem. Ecol., 2: 251261. https://doi.org/10.1080/02757548608080730

Nawaz, S., Nagra, S.A., Saleem, Y. and Priydarshi, A., 2010. Determination of heavy metals in fresh water fish species of the River Ravi, Pakistan compared to farmed fish varieties. Environ. Monitor. Assess., 167: 461-471. https://doi.org/10.1007/s10661-0091064-9

Pandey, M., Pandey, A.K., Mishra, A. and Tripathi, B.D., 2017. Assessment of metal bioaccumulation in Mastacembelus armatus (eel) and exposure evaluation in human. Environ. Nanotechnol. Monitor. Manage., 7: 103-109.

Rauf, A., Javed, M. and Ubaidullah, M., 2009. Heavy metal levels in three major carps (Catla catla, Labeo rohita and Cirrhina mrigala) from the river Ravi, Pakistan. Pak. Vet. J., 29: 24-26.

Siraj, M., Shaheen, M., Sthanadar, A.A., Khan, A., Chivers, D.P. and Yousafzai, A.M., 2014. A comparative study of bioaccumulation of heavy metals in two fresh water species, Aorichthys seenghala and Ompok bimaculatous at River Kabul, Khyber Pakhtunkhwa, Pakistan. J. Biodiver. environ. Sci., 4: 40-54.

Tabinda, A.B., Bashir, S., Yasar, A. and Munir, S., 2013. Heavy metals concentrations in water, sediment and fish in River Sutlej at Sulemanki Headworks. Pakistan J. Zool., 45: 1663-1668.

Tariq, J., Jaffar, M. and Ashraf, M., 1991. Levels of selected heavy metals in commercial fish from five freshwater lakes, Pakistan. Toxicol. environ. Chem., 33: 133-140. https://doi. org/10.1080/02772249109357755

Usman, K., Zaib-un-Nisa, Gul, S., Gul, S., Rehman, H.U., Asad, M., Waqar, M., Ullah, K. and Ishaq, H.K., 2017. Contamination of heavy metals in River Shah Alam Peshawar: (A tributary of River Kabul) Khyber Pakhtunkhwa Pakistan. J. Ent. Zool. Stud., 5: 510-512.

Yousafzai, A.M. and Shakoori, A.R., 2008. Heavy metal accumulation in the gills of an endangered South Asian fresh water fish as an indicator of aquatic pollution. Pakistan J. Zool., 40: 423-430. 